Article

\title{
An Exploratory Study of a New Psychological Instrument for Evaluating Sustainability: The Sustainable Development Goals Psychological Inventory
}

\author{
Annamaria Di Fabio ${ }^{1, *(1)}$ and Marc A. Rosen ${ }^{2}$ (1) \\ 1 Department of Education, Languages, Intercultures, Literatures and Psychology (Psychology Section), \\ University of Florence, 50135 Florence, Italy \\ 2 Faculty of Engineering and Applied Science, University of Ontario Institute of Technology, \\ Oshawa, ON L1G 0C5, Canada; Marc.Rosen@uoit.ca \\ * Correspondence: adifabio@psico.unifi.it; Tel.: +39-(0)55-2055850
}

Received: 14 May 2020; Accepted: 10 September 2020; Published: 16 September 2020

\begin{abstract}
The psychometric properties of the Sustainable Development Goals Psychological Inventory (SDGPI) are verified, by employing quantitative and qualitative approaches, in order to obtain a thorough comprehension of the self-perceptions of the sustainable development goals by the Italian participants in this research. The reliability, dimensionality, and aspects of concurrent validity were tested for the SDGPI. Three unidimensional factors (interest, motivation, and self-efficacy) were shown to be prevalent using exploratory factor analysis. Furthermore, the SDGPI showed adequate concurrent validity and internal consistency in the present study. To broaden the quantitative findings, responses to open-ended questions were analyzed. The results suggest perspectives for future exploration and actions regarding the psychology of sustainable development and sustainability.
\end{abstract}

Keywords: sustainable development goals; sustainable development goals psychological inventory; psychology of sustainability; psychology of sustainable development; interest; motivation; self-efficacy

\section{Introduction}

Sustainability science [1-4] generates a reflection space that is transdisciplinary, connecting the humanities, social sciences, and applied and natural sciences. It focuses on examining interactions among engineered, environmental, and human systems [1-3] to explain the complex factors implicated in their degradation, with a view to preserving the Earth for the future and enhancing civilizations and human well-being. Sustainability science [5] contributes to achieving the Sustainable Development Goals (SDGs) of the United Nations (UN) [6], by pulling together disparate disciplines to realize sustainable development.

The psychology of sustainable development and sustainability [5-8] represents a relatively new sustainability science research area, enhancing the multidisciplinary outline that underpins this field by introducing a psychological perspective, which is also applicable to many other environments. The opening of the "black box" of psychological processes represents a new opportunity [5] for more concrete sustainable development currently and in the future.

Psychological processes are intrinsically implied in decisions and behavior regarding environmental issues, and in advancing and setting up a culture of environmental sustainability. This area of psychology [5-8] overcomes the established framework of the three "E's" (environment, economy, equity) $[9,10]$, focusing on not just utilizing ever-decreasing supplies of resources, but likewise revitalizing strengths from a positive viewpoint. New keywords and a new narrative emerge here [5-8]: 
a perspective linked to promoting, enriching, growing and flexibly changing. This perspective thus overwhelms the traditional definition of sustainability centered on "avoiding" something, considering exploitation, consumption, and permanent alteration. In fact, it presents a new definition that underlines promotion and the processes implied.

Within the field of the psychology of sustainable development and sustainability [5-8], the quality of life and well-being of each individual in an individual's environment are central. Note that here we refer to the natural environment as well as other types of environments; this extends not only to the well-being of the individual but also to that of the individual's environments, whether they be natural, personal, social, organizational, community, digital, cross-cultural, or global.

This area of psychology [5-8] also implements a perspective of investigation and intervention within a primary prevention framework [11-15] and strength-based prevention perspectives [16-19].

In this preventative framework, the new research area of the psychology of sustainability and sustainable development [5-8] underlines the relevance of an assessment that considers specific psychological aspects in connection with the Sustainable Development Goals (SDGs) of the United Nations [6]. The assessment of psychological aspects connected to the UN SDGs could permit the individuating of psychological areas of intervention to promote the achievement of the SDGs.

The UN SDGs [6] encompass major global challenges, such as environmental degradation and climate change, human well-being and prosperity, poverty and inequality, and peace and justice. In particular, Goal 1, "No poverty", aims to achieve everywhere an end to all forms of poverty. Goal 2, "Zero hunger" seeks improved nutrition and food security, in part through sustainable agriculture. Goal 3, "Good health and well-being", is concerned with ensuring well-being and healthy lives for everyone. This topic is currently taking on a much greater importance in the context of the COVID-19 pandemic. The world is facing a global health crisis due to COVID-19 that is spreading human suffering and threatening the global economy. To have an instrument that permits reflection on the health and well-being from a psychological point of view could open new perspectives for sustainability and sustainable development not just in general, but also in the context of the COVID-19 pandemic. However, it is pointed out that the present survey was conducted before the pandemic and thus the results presented here do not take the pandemic into account. Goal 4, "Quality education", aspires for education for all that is of a high-quality, inclusive and equitable, including lifelong learning. Goal 5, "Gender equality", seeks, in particular, to empower all women and girls. Goal 6, "Clean water and sanitation", is concerned with ensuring the availability for all of clean water and sanitation, and their sustainable management. Goal 7, "Affordable and clean energy", aims at the provision for all of reliable, sustainable and affordable energy. Goal 8, "Decent work and economic growth", seeks inclusive and sustainable economic growth with productive and full employment, reducing unemployment and including decent work to enable people to earn a living. Goal 9, "Industry, innovation, and infrastructure", promotes sustainable industrialization and innovation, as well as a resilient infrastructure. Goal 10, "Reduced inequalities", is about reducing inequalities among countries and within them. Goal 11, "Sustainable cities and communities", aims for resilient, inclusive, safe, and sustainable cities and human settlements. Goal 12, "Responsible consumption and production", deals with patterns of consumption and production that are sustainable. Goal 13, "Climate action", is an exhortation for urgent action to mitigate climate change and its impacts. Goal 14 , "Life below water", is about conserving oceans, seas, and marine resources and using them sustainably. Goal 15, "Life on land", is concerned with protecting and restoring terrestrial ecosystems and ensuring their sustainable use, stopping and reversing biodiversity loss and land degradation, including desertification, and managing forests sustainably. Goal 16, "Peace, justice, and strong institutions", promotes inclusive and peaceful societies with justice for all as well as effective, inclusive and accountable institutions. Finally, Goal 17, "Partnerships for the goals", seeks productive global partnerships for sustainable development and its implementation. The UN SDGs are considered crucial by many countries, even if there are differences in the importance accorded to each and in the strategies to implement them. Many recent studies have discussed the important processes, actors, 
and aspects of the SDGs [20-27] For instance, the roles of universities as contributors to achieving sustainable development have been examined by Rosen [28]. The psychology of sustainability and sustainable development [5-8] does not represent a sporadic contribution to sustainability issues but rather recognizes the value of a psychological approach in the construction of sustainability and sustainable development processes.

The present study offers a new contribution to critical psychological aspects related to the self-perception of the SDGs, in terms of interest, motivation, and self-efficacy, which are traditional variables in psychology. Socio-cognitive theory $[29,30]$ connects interest and self-efficacy. In this theory, self-efficacy is the fundamental variable. It refers to the judgment that individuals make of their ability to organize and implement a series of actions that may be required in certain types of performance or activity [29]. In a socio-cognitive vision, self-efficacy does not represent a global trait but rather the dynamic core of a person linked to domain-specific performances [29]. In the interests model [31], self-efficacy and response expectations contribute to modulating interests: interest in a specific activity develops when individuals perceive themselves to be efficacious and anticipate positive outcomes; by contrast, they will maintain a disinterest in those activities in which they doubt their potential to succeed and where neutral or negative outcomes are foreseen. Interests lead to intentions for further activities, increasing the likelihood of subsequent practice. Practice can produce successes, which in turn can increase self-efficacy in a specific activity [30,31].

Another psychological theory, Self-Determination Theory (SDT) [32-34], links interest with motivation. SDT distinguishes intrinsic and extrinsic motivation, as well as amotivation (a lack of motivation). Intrinsic motivation is the inherently natural guide to watch for chances and new opportunities. SDT connects this kind of motivation with cognitive and social growth [32]. External sources are at the base of extrinsic motivation [32]. Amotivation is a non-self-determined form of motivation involving an absence of extrinsic and intrinsic motivation. Interest contributes to intrinsic motivation by initiating and directing attention and exploratory behavior [35].

Self-efficacy and motivation are also linked to performance. Social Cognitive Theory (SCT) [29] and self-determination theory (SDT) [32-34] lay the foundation for a better understanding of performance. SCT underlines that self-efficacy and performance are positively associated [29] and SDT points out that a higher performance is related to more self-regulated types of motivation [32].

Starting from these traditional theories, more complex models have recently been developed, in particular, in the field of science and math. Considering the reciprocal influences between interest and self-efficacy [36], Chen et al. [37], using latent growth models with middle school students, found that: (1) "students' preintervention self-efficacy for science had an effect both on students' triggered situational interest for an Ecosystems Multi-User Virtual Environment (EcoMUVE) and on students' maintained situational interest for EcoMUVE; (2) both triggering and maintaining situational interest in EcoMUVE were important in developing students' science self-efficacy. In fact, maintained situational interest was the stronger predictor; (3) maintained situational interest for EcoMUVE translated into individual interest for the science content" [37], p. 11. These findings are in line with SDT, supporting models of development of interests.

On the basis of some premises of Social Cognitive Career Theory (SCCT) [30], Grigg et al. [38] developed an integrative model to explain math success for early and middle teenagers. SCCT proposes that students' self-efficacy views influence their interest [30], such that students who think they are able to perform well in math activities may develop an interest in math [39]. SCCT [30] highlights that academic self-efficacy views are reciprocally associated with domain-related performance, since self-efficacy and achievement are able to reinforce each other. Interests are also associated with achievement, since achievement can be fostered by interests through enhancing attention and engagement [40]. Furthermore, SCCT [30] identifies a principal path from interests to intentions, although some authors [41] favor the concept of reciprocal effects. With regard to the association of intentions with success, research $[42,43]$ shows that math achievement is related to increased intentions for following educational and career pathways that are related to math. On these theoretical bases, Grigg et 
al. [38] verified a model for the interaction among math aspirations, interests and self-efficacy, and achievement referring to the target of adolescents. Their longitudinal study showed that "(a) math self-efficacy positively predicted math achievement using both class grades and standardized test score operationalizations; (b) prior math achievement positively predicted basal levels of math self-efficacy but not changes in self-efficacy; (c) math interest and intentions were reciprocally linked over time; (d) prior math interest positively predicted subsequent math self-efficacy, whereas the opposite was not true" [38], p. 73. The study results underline that, in particular, math self-efficacy contributes strongly to positive changes in math achievement, in addition to the outcomes of previous successes, also reaffirming the value of interest [38].

A recent study [44] proposed an integrated explanation of the relationship among interest, motivation, and performance. The results of this study showed that working on a highly intrinsically motivating initial task caused participants to perform worse in a subsequent task if it was perceived as uninteresting, but not if it was perceived as interesting. Furthermore, moderate intrinsic motivation in one task was related with better performance in less interesting tasks than high intrinsic motivation, showing a curvilinear cross-task effect of intrinsic motivation.

Interest, motivation, and self-efficacy are also related to the concept of goals. Following a traditional perspective, Elliot and Fryer [45] underlined that a goal is a central construct in motivation theories. It is practically impossible to conceptualize motivation without considering that behavior has a goal directed nature. A goal construct is included in traditional motivation theories. For example, Mitchell [46] defined motivation as "those psychological processes that cause the arousal, direction, and persistence of voluntary actions that are goal directed" [46], (p. 81). Phares and Chaplin ([47], p. 434) defined motivation as "the forces within us that activate our behavior and direct it toward one goal rather than another". In the literature there are many different definitions of goals from a psychological point of view [45]. Some of these definitions reference a desired possibility [48], while others reference a focus on the future [49], internal representations [50], movement and a focal point of this movement [51], and commitment [52]. Social cognitive theory (SCT) [29] and self-determination theory (SDT) [32-34] also contributed to the conceptualization of the goal construct from a psychological point of view. In the framework of social cognitive theory (SCT) [29], Dweck [53] assumed that individuals with learning goals were supposed to approach situations with the goal of mastering the achievement of new skills, while individuals with performance goals were supposed to approach situations with the goal of obtaining positive judgment of their competence and approval from others. Goal research based on self-determination theory has offered evidence that goal striving is most successful and adaptive when it has intrinsic, need-satisfying aspirations [32-34].

With reference to the 17 SDGs, considering the crucial importance in the psychological literature of interest, motivation and self-efficacy linked to the actions and performance of individuals, Di Fabio and Rosen propose for the first time in this article the Sustainable Development Goals Psychological Inventory (see Appendix A) to study in-depth the critical psychological components for successful performance related to the seventeen SDGs. The administration of this inventory allows new awareness related to these critical psychological components for many aims: to carry out surveys for knowledge purposes regarding the modernity of the self-perception of the goals made by people; to prepare tailor-made interventions in relation to different targets, contexts and countries on the basis of findings that emerge; to use the administration of the inventory both in urgent situations when it is vital to intervene to change something knowing the critical ingredients linked to performance in the self-perceptions of people, and above all, in a psychoeducational strength-based preventive perspective [54], to facilitate the structuring of interests, motivations and self-efficacy in relation to the seventeen sustainable development goals. The administration of the inventory provides a new awareness of the goals that are perceived as less important and specific contexts and countries, so as to be able to act with specific interventions.

Attention to the promotion of sustainable development goals could be related to constructs relative to the care and consideration of the natural world and of other people as well as aspects relative 
to purpose in terms of meaningfulness and self-orientation. Constructs such as connectedness to nature [55], empathy [56], compassion [57] and purpose [58] could be introduced. Connectedness to nature refers to the degree to which a person incorporates nature within his/her cognitive representation of self; this represents an individual's affective, experiential connection to nature [55]. Empathy could be seen as reactions of an individual to the observed experiences of another [56]. Compassion regards a strong feeling of sympathy and sadness for the suffering or bad luck of others and a wish to help them [57]. Finally, purpose is defined as an enduring and foresighted intention to reach significant goals for oneself and for the broader world [58]. For the analysis of aspects of the concurrent validity of the Sustainable Development Goals Psychological Inventory, the relationships with connectedness to nature, empathy, compassion, purpose are examined.

The present study is aimed at reaching a better awareness of how sustainable development goals are perceived and can be assessed, taking into account critical psychological components. The inventory responds to the aim of detecting interest, motivation and self-efficacy as relevant psychological variables to facilitate the understanding of the self-perceptions of people in relation to the seventeen sustainable development goals. The inventory also aims to make a contribution to the purpose of structuring more tailor-made interventions, highlighting specific needs in relation to different targets, areas and national and international contexts. To attain this study's first objective, we verify the psychometric properties of the sustainable development goals inventory by employing a quantitative approach (first part of the study). We also integrate a qualitative approach in order to provide a more thorough comprehension of the self-perceptions of the SDGs according to the viewpoints of the participants (second part of the study). This work is viewed as an essential complement to technically-oriented studies on sustainable development that cover areas such as energy, water, the environment, and climate change [1,59].

\section{Method}

\section{Participants}

The study involved 368 Italian participants having a mean age of 40.55 (SD = 15.20; range 19-65 years). A total of 161 were males (43.75\%) and 207 were females (56.25\%). In total, 236 were workers $(64.13 \%)$ and 132 were students $(35.87 \%)$. The study participants completed the survey of the Sustainable Development Goals Psychological Inventory (SDGPI) shown in Appendix A. Of the total, 212 participants also completed other measures to test for aspects of concurrent validity. The participants filled in the questionnaires voluntarily and they did not receive any kind of reward.

\section{Instruments}

\subsection{Quantitative Instruments}

The SDGPI was devised by Di Fabio and Rosen for the first time in this study and is composed of 51 items, 17 items for each of the three factors, interest, motivation, and self-efficacy. The 17 items for each of the factors correspond to the 17 SDGs. The participants were asked to rank (1) their interest in each SDG for the interest factor, (2) their motivation to take practical action toward achieving each of the SDGs for the motivation factor, and (3) their self-efficacy to take practical action toward achieving each of the SDGs for the self-efficacy factor. There were five possible rankings for each item, ranging from $1=$ not at all to $2=$ a little, $3=$ somewhat, $4=$ quite a lot, and $5=$ very much.

To assess connectedness to nature, the Connectedness to Nature Scale (CNS [55]; Italian version by Di Fabio [60]) was utilized. That scale includes 14 items with an answer format on a 5-point Likert scale, ranging from $5=$ strongly disagree to $1=$ strongly agree. The Cronbach's alpha coefficient was found to be 0.91 [60].

The Interpersonal Reactivity Index (IRI) [56], in the Italian version by Albiero, Ingoglia, and Lo Coco [61], was utilized to evaluate empathy. The IRI includes 28 items with response options on a four-point Likert scale, ranging from $4=$ always true to $1=$ never true. Scores on four dimensions 
(fantasy, empathic concern, perspective-taking, and personal distress) are provided by the measure along with a total score. The Cronbach's alpha coefficient for the total score was 0.84 [61]. In the present study, the total IRI score is used.

To evaluate compassion, the Compassion Scale (CS) [57], using the Italian version by Di Fabio [62], was employed. That scale includes 22 items with a 7-point Likert scale response format (from $7=$ completely true of me to $1=$ not at all true of me). A total score was provided along with a score on each of five dimensions: recognizing suffering, understanding the universality of suffering, emotional connection, tolerating uncomfortable feelings, and acting to help/alleviate suffering. The Cronbach's alpha coefficient was 0.85 [62]. The total CS score was used in the present study.

To evaluate purpose, the Claremont Purpose Scale (CPS) [58]-the Italian version by Di Fabio and Kenny [63] — was administered. That questionnaire has 12 items on a 5-point Likert scale and assesses three dimensions: personal meaningfulness, goal orientation, and self-transcendence (i.e., aspects beyond the self). The Cronbach's alpha coefficient was 0.90 [63]. The total score of the CPS was used in the present study.

\subsection{Qualitative Instruments}

To obtain a more thorough comprehension of the participants' self-perceptions of the SDGs, the survey included open-ended questions. Participants were asked the following questions: "Which of the 17 Sustainable Development Goals is the most important for me? Why?"; "Which of the 17 Sustainable Development Goals is the least important for me? Why?". As shown in the following section, the participants' responses were analyzed utilizing the conventional content analysis procedure of Hsieh and Shannon [64].

\subsection{Data Analysis}

Specialist personnel administered the questionnaires in groups considering the Italian legal requirements for informed consent and privacy in the period between September and December 2019. For controlling any effects due to the order of presentation, attention was paid to counterbalance the order of presentation of the questionnaires.

Regarding quantitative analysis, the factorial structure of the SDGPI was examined by means of exploratory factor analysis (EFA) (principal axis factoring). Three factor analyses were carried out, one with each dimension (interest, motivation, self-efficacy). The reliability of the three factors was verified by calculating Cronbach's alpha. Further, to verify aspects of the concurrent validity factors, the Pearson r correlations of the SDGPI with the CNS, IRI, CS, and CPS were computed. T-test analyses for gender and age effect were carried out, but no significant differences emerged.

The qualitative analysis aimed to obtain a thorough comprehension of the self-perceptions of the sustainable development goals by the participants in this research. This qualitative analysis permits the integration of the results of the quantitative questionnaire with qualitative information about the importance of SDGs for participants. The questions were written and administered after the quantitative questionnaire. The following four questions were asked: "Which of the 17 Sustainable Development Goals is the most important for me? Why?"; "Which of the 17 Sustainable Development Goals is the least important for me? Why?". These specific questions were used to obtain more information about the self-perception of the importance of the sustainable development goals for participants in the present study. Participants' responses to these open-ended questions were analyzed using a conventional content analysis [64]. With this qualitative research method, the text data content is identified through a systematic classification process, which includes coding procedures and careful theme recognition [64]. Responses offered by participants were organized in categories. Researchers using conventional content analysis derived codes and categories directly on the base of text data [64], because they used neither preconceived categories nor a theory-based coding system. This contrasts with other types of qualitative data analysis, such as consensual qualitative research and grounded theory [64]. 
A first assessor started by analyzing the participants' responses to open-ended questions, examining participants' answers considering themes, and deriving a classification relating to the main categories. Two independent assessors afterwards controlled the data and analyses, recommending changes in categories and the allocation of responses for them, based on the conventional approach in qualitative research [65]. The three assessors resolved the inconsistencies to achieve a consensus.

\section{Results}

\subsection{Validation of the Inventory}

The results of the EFA showed three unidimensional factors. For the first factor analysis, the Kaiser-Meyer-Olkin (KMO) statistic showed a value of 0.89 , indicating that the sampling was adequate. The Barlett sphericity test was significant $(p<0.001)$, indicating that a factor analysis would be useful with these data.

The interest factor explained $42.95 \%$ of variance and exhibited a Cronbach's alpha of 0.91 . Table 1 lists the factor loadings for the 17 items of this factor. The factor loadings ranged from 0.73 to 0.50 .

Table 1. Factor loadings and item-total statistics for the interest factor.

\begin{tabular}{|c|c|c|c|c|c|c|}
\hline $\begin{array}{c}\text { Sustainable } \\
\text { Development Goal }\end{array}$ & $\begin{array}{l}\text { Factor } \\
\text { Loading }\end{array}$ & $\begin{array}{c}\text { Scale Mean } \\
\text { if Item } \\
\text { Deleted }\end{array}$ & $\begin{array}{l}\text { Scale Variance } \\
\text { if Item Deleted }\end{array}$ & $\begin{array}{l}\text { Corrected } \\
\text { Item-Total } \\
\text { Correlation }\end{array}$ & $\begin{array}{c}\text { Squared } \\
\text { Multiple } \\
\text { Correlation }\end{array}$ & $\begin{array}{l}\text { Cronbach's } \\
\text { Alpha if Item } \\
\text { Deleted }\end{array}$ \\
\hline $\begin{array}{l}\text { 11. Sustainable cities } \\
\text { and communities } \\
\text { 12. Responsible }\end{array}$ & 0.73 & 66.22 & 94.59 & 0.69 & 0.61 & 0.91 \\
\hline $\begin{array}{l}\text { consumption and } \\
\text { production }\end{array}$ & 0.69 & 66.13 & 94.82 & 0.66 & 0.62 & 0.91 \\
\hline $\begin{array}{l}\text { 10. Reduced } \\
\text { inequalities }\end{array}$ & 0.68 & 66.04 & 94.15 & 0.65 & 0.55 & 0.91 \\
\hline 1. No poverty & 0.66 & 66.19 & 93.39 & 0.63 & 0.76 & 0.91 \\
\hline $\begin{array}{c}\text { 7. Affordable and clean } \\
\text { energy }\end{array}$ & 0.65 & 65.95 & 96.00 & 0.61 & 0.56 & 0.91 \\
\hline 2. Zero hunger & 0.65 & 66.07 & 93.66 & 0.62 & 0.75 & 0.91 \\
\hline $\begin{array}{l}\text { 8. Decent work and } \\
\text { economic growth }\end{array}$ & 0.65 & 65.93 & 96.68 & 0.61 & 0.46 & 0.91 \\
\hline $\begin{array}{l}\text { 9. Industry, innovation } \\
\text { and infrastructure }\end{array}$ & 0.64 & 66.25 & 94.66 & 0.61 & 0.49 & 0.91 \\
\hline 15. Life on land & 0.63 & 66.17 & 94.21 & 0.62 & 0.49 & 0.91 \\
\hline $\begin{array}{l}\text { 6. Clean water and } \\
\text { sanitation }\end{array}$ & 0.63 & 65.85 & 96.77 & 0.59 & 0.47 & 0.91 \\
\hline $\begin{array}{l}\text { 16. Peace, justice and } \\
\text { strong institutions }\end{array}$ & 0.62 & 65.95 & 96.42 & 0.60 & 0.43 & 0.91 \\
\hline $\begin{array}{l}\text { 3. Good health and } \\
\text { well-being }\end{array}$ & 0.62 & 65.87 & 97.32 & 0.59 & 0.52 & 0.91 \\
\hline 13. Climate action & 0.59 & 66.06 & 95.16 & 0.56 & 0.49 & 0.91 \\
\hline 4. Quality education & 0.57 & 65.91 & 97.24 & 0.54 & 0.40 & 0.91 \\
\hline 14. Life below water & 0.57 & 66.81 & 91.29 & 0.55 & 0.43 & 0.91 \\
\hline $\begin{array}{l}\text { 17. Partnerships for the } \\
\text { goals }\end{array}$ & 0.56 & 66.59 & 94.40 & 0.54 & 0.40 & 0.91 \\
\hline 5. Gender equality & 0.50 & 66.01 & 97.67 & 0.47 & 0.42 & 0.91 \\
\hline
\end{tabular}

For the second factor analysis, the Kaiser-Meyer-Olkin (KMO) statistic showed a value of 0.93 , indicating that the sampling was adequate. The Barlett sphericity test was significant $(p<0.001)$, indicating that a factor analysis would be useful with these data. The motivation factor explained $51.96 \%$ of variance and exhibited a Cronbach's alpha of 0.94 . Table 2 reports the factor loadings for the 17 items of this factor. The range of the factor loadings was from 0.77 to 0.60 . 
Table 2. Factor loadings and item-total statistics for the motivation factor.

\begin{tabular}{|c|c|c|c|c|c|c|}
\hline $\begin{array}{c}\text { Sustainable } \\
\text { Development Goal }\end{array}$ & $\begin{array}{l}\text { Factor } \\
\text { Loading }\end{array}$ & $\begin{array}{l}\text { Scale Mean } \\
\text { if Item } \\
\text { Deleted }\end{array}$ & $\begin{array}{l}\text { Scale Variance } \\
\text { if Item Deleted }\end{array}$ & $\begin{array}{l}\text { Corrected } \\
\text { Item-Total } \\
\text { Correlation }\end{array}$ & $\begin{array}{c}\text { Squared } \\
\text { Multiple } \\
\text { Correlation }\end{array}$ & $\begin{array}{l}\text { Cronbach's } \\
\text { Alpha if Item } \\
\text { Deleted }\end{array}$ \\
\hline $\begin{array}{l}\text { 11. Sustainable cities } \\
\text { and communities }\end{array}$ & 0.77 & 60.11 & 155.46 & 0.74 & 0.63 & 0.94 \\
\hline $\begin{array}{l}\text { 16. Peace, justice and } \\
\text { strong institutions }\end{array}$ & 0.76 & 59.90 & 156.10 & 0.73 & 0.63 & 0.94 \\
\hline $\begin{array}{l}\text { 7. Affordable and clean } \\
\text { energy }\end{array}$ & 0.75 & 59.87 & 157.75 & 0.72 & 0.69 & 0.94 \\
\hline $\begin{array}{l}\text { 12. Responsible } \\
\text { consumption and } \\
\text { production }\end{array}$ & 0.74 & 60.00 & 156.48 & 0.71 & 0.61 & 0.94 \\
\hline $\begin{array}{l}\text { 6. Clean water and } \\
\text { sanitation }\end{array}$ & 0.73 & 59.83 & 157.66 & 0.70 & 0.61 & 0.94 \\
\hline $\begin{array}{l}\text { 9. Industry, innovation } \\
\text { and infrastructure }\end{array}$ & 0.72 & 60.19 & 155.86 & 0.70 & 0.60 & 0.94 \\
\hline 13. Climate action & 0.72 & 59.81 & 157.32 & 0.69 & 0.58 & 0.94 \\
\hline 1. No poverty & 0.71 & 60.13 & 156.24 & 0.69 & 0.81 & 0.94 \\
\hline $\begin{array}{l}\text { 10. Reduced } \\
\text { inequalities }\end{array}$ & 0.71 & 59.89 & 156.97 & 0.69 & 0.58 & 0.94 \\
\hline 15. Life on land & 0.70 & 60.16 & 154.93 & 0.69 & 0.58 & 0.94 \\
\hline $\begin{array}{l}\text { 17. Partnerships for the } \\
\text { goals }\end{array}$ & 0.69 & 60.45 & 154.93 & 0.67 & 0.54 & 0.94 \\
\hline 4. Quality education & 0.68 & 59.75 & 159.64 & 0.66 & 0.54 & 0.94 \\
\hline 2. Zero hunger & 0.68 & 60.05 & 156.55 & 0.66 & 0.80 & 0.94 \\
\hline $\begin{array}{l}\text { 3. Good health and } \\
\text { well-being }\end{array}$ & 0.67 & 59.76 & 159.94 & 0.64 & 0.52 & 0.94 \\
\hline $\begin{array}{l}\text { 8. Decent work and } \\
\text { economic growth }\end{array}$ & 0.66 & 59.78 & 159.97 & 0.64 & 0.48 & 0.94 \\
\hline 5. Gender equality & 0.62 & 59.80 & 159.81 & 0.60 & 0.49 & 0.94 \\
\hline 14. Life below water & 0.60 & 60.59 & 155.61 & 0.58 & 0.47 & 0.94 \\
\hline
\end{tabular}

For the third factor analysis, the Kaiser-Meyer-Olkin (KMO) statistic showed a value of 0.92 , indicating that sampling was adequate. The Barlett sphericity test was significant $(p<0.001)$, indicating that a factor analysis would be useful with these data. The self-efficacy factor explained $52.87 \%$ of variance and showed a Cronbach's alpha of 0.94 . Table 3 lists the factor loadings for the 17 items of this factor. The factor loadings ranged from 0.76 to 0.61 .

Table 3. Factor loadings and item-total statistics for the self-efficacy factor.

\begin{tabular}{|c|c|c|c|c|c|c|}
\hline $\begin{array}{c}\text { Sustainable } \\
\text { Development Goal }\end{array}$ & $\begin{array}{l}\text { Factor } \\
\text { Loading }\end{array}$ & $\begin{array}{c}\text { Scale Mean } \\
\text { if Item } \\
\text { Deleted }\end{array}$ & $\begin{array}{l}\text { Scale Variance } \\
\text { if Item Deleted }\end{array}$ & $\begin{array}{l}\text { Corrected } \\
\text { Item-Total } \\
\text { Correlation }\end{array}$ & $\begin{array}{c}\text { Squared } \\
\text { Multiple } \\
\text { Correlation }\end{array}$ & $\begin{array}{l}\text { Cronbach's } \\
\text { Alpha if Item } \\
\text { Deleted }\end{array}$ \\
\hline $\begin{array}{l}\text { 8. Decent work and } \\
\text { economic growth }\end{array}$ & 0.76 & 46.92 & 182.86 & 0.73 & 0.65 & 0.94 \\
\hline $\begin{array}{l}\text { 11. Sustainable cities } \\
\text { and communities }\end{array}$ & 0.76 & 47.09 & 183.62 & 0.74 & 0.63 & 0.94 \\
\hline $\begin{array}{l}\text { 6. Clean water and } \\
\text { sanitation }\end{array}$ & 0.75 & 47.09 & 183.99 & 0.73 & 0.69 & 0.94 \\
\hline $\begin{array}{l}\text { 7. Affordable and clean } \\
\text { energy }\end{array}$ & 0.75 & 47.09 & 184.78 & 0.73 & 0.68 & 0.94 \\
\hline $\begin{array}{l}\text { 9. Industry, innovation } \\
\text { and infrastructure }\end{array}$ & 0.73 & 47.24 & 184.72 & 0.71 & 0.64 & 0.94 \\
\hline $\begin{array}{l}\text { 10. Reduced } \\
\text { inequalities }\end{array}$ & 0.73 & 46.79 & 183.91 & 0.71 & 0.61 & 0.94 \\
\hline $\begin{array}{l}\text { 16. Peace, justice and } \\
\text { strong institutions }\end{array}$ & 0.73 & 46.96 & 184.17 & 0.71 & 0.59 & 0.94 \\
\hline 15. Life on land & 0.72 & 47.09 & 183.85 & 0.70 & 0.64 & 0.94 \\
\hline 2. Zero hunger & 0.70 & 47.33 & 185.67 & 0.68 & 0.77 & 0.94 \\
\hline
\end{tabular}


Table 3. Cont.

\begin{tabular}{ccccccc}
\hline $\begin{array}{c}\text { Sustainable } \\
\text { Development Goal }\end{array}$ & $\begin{array}{c}\text { Factor } \\
\text { Loading }\end{array}$ & $\begin{array}{c}\text { Scale Mean } \\
\text { if Item } \\
\text { Deleted }\end{array}$ & $\begin{array}{c}\text { Scale Variance } \\
\text { if Item Deleted }\end{array}$ & $\begin{array}{c}\text { Corrected } \\
\text { Item-Total } \\
\text { Correlation }\end{array}$ & $\begin{array}{c}\text { Squared } \\
\text { Multiple } \\
\text { Correlation }\end{array}$ & $\begin{array}{c}\text { Cronbach's } \\
\text { Alpha if Item } \\
\text { Deleted }\end{array}$ \\
\hline $\begin{array}{c}\text { 3. Good health and } \\
\text { well-being }\end{array}$ & 0.70 & 46.86 & 185.33 & 0.68 & 0.54 & 0.94 \\
$\begin{array}{c}\text { 12. Responsible } \\
\text { consumption and }\end{array}$ & 0.70 & 46.69 & 184.87 & 0.67 & 0.62 & 0.94 \\
$\begin{array}{c}\text { production } \\
\text { 1. No poverty }\end{array}$ & 0.68 & 47.38 & 187.11 & 0.66 & 0.76 & 0.94 \\
4. Quality education & 0.68 & 46.90 & 186.10 & 0.66 & 0.52 & 0.94 \\
5. Gender equality & 0.67 & 46.74 & 185.64 & 0.66 & 0.53 & 0.94 \\
13. Climate action & 0.67 & 46.74 & 185.72 & 0.67 & 0.60 & 0.94 \\
17. Partnerships for the & 0.67 & 47.35 & 185.25 & 0.64 & 0.51 & 0.94 \\
$\begin{array}{c}\text { goals } \\
\text { 14. Life below water }\end{array}$ & 0.61 & 47.48 & 186.32 & 0.59 & 0.53 & 0.94 \\
\hline
\end{tabular}

Descriptive statistics for each factor (including lowest and highest scores for each factor) are reported in Table 4.

Table 4. Descriptive statistics for each factor.

\begin{tabular}{ccccc}
\hline Factor & $\boldsymbol{M}$ & $\boldsymbol{D S}$ & $\boldsymbol{M I N}$ & $\boldsymbol{M A X}$ \\
\hline SDGS Interest & 70.25 & 10.34 & 45 & 85 \\
SDGS Motivation & 63.76 & 13.29 & 17 & 85 \\
SDGS Self-efficacy & 49.98 & 14.42 & 17 & 85 \\
\hline
\end{tabular}

The matrix of intercorrelations among factors is showed in Table 5.

Table 5. Matrix of intercorrelations among factors.

\begin{tabular}{cccc}
\hline Factor & 1. SDGS Interest & 2. SDGS Motivation & 3. SDGS Self-Efficacy \\
\hline 1. SDGS Interest & $0 . \overline{9}^{* *}$ & $\overline{-}^{* *}$ & \\
2. SDGS Motivation & $0.31^{* *}$ & $0.65^{* *}$ & - \\
3. SDGS Self-efficacy & ${ }^{* *} p<0.01$.
\end{tabular}

The correlations of the SDGPI with the CNS, IRI, CS, and CPS are presented in Table 6.

Table 6. Correlation of the SDGS with the CNS, IRI, CN, and CPS.

\begin{tabular}{|c|c|c|c|c|}
\hline & CNS & IRI & CS & CPS \\
\hline SDGS Interest & $0.45^{* *}$ & $0.44^{* *}$ & $0.41^{* *}$ & $0.30 * *$ \\
\hline SDGS Motivation & $0.31^{* *}$ & $0.38^{* *}$ & $0.31 * *$ & $0.35^{* *}$ \\
\hline SDGS Self-efficacy & $0.34^{* *}$ & $0.30 * *$ & $0.30 * *$ & $0.41^{* *}$ \\
\hline
\end{tabular}

\subsection{Qualitative Study}

To analyze the responses of 368 participants to open-ended questions, the conventional content analysis procedures previously delineated were used.

For the questions: "Which of the 17 Sustainable Development Goals is the most important for me?", the answer frequency with respect to each of the 17 SDGs is reported in Table 7. Some participants answered in a general way, reporting, "All goals are important for me". 
Table 7. Answers to "Which of the 17 Sustainable Development Goals is the most important for me?".

\begin{tabular}{lcc}
\hline \multicolumn{1}{c}{ Sustainable Development Goal } & Frequency of Answer & \% of Responses \\
\hline 4. Quality education & 52 & 14.13 \\
3. Good health and well-being & 48 & 13.04 \\
1. No poverty & 46 & 12.50 \\
13. Climate action & 44 & 11.96 \\
10. Reduced inequalities & 33 & 8.97 \\
2. Zero hunger & 29 & 7.88 \\
0. All goals are important for me & 27 & 7.34 \\
8. Decent work and economic growth & 26 & 7.07 \\
16. Peace, justice, and strong institutions & 14 & 3.80 \\
5. Gender equality & 12 & 3.26 \\
12. Responsible consumption and production & 10 & 2.72 \\
7. Affordable and clean energy & 7 & 1.90 \\
6. Clean water and sanitation & 6 & 1.63 \\
9. Industry, innovation, and infrastructure & 6 & 1.63 \\
17. Partnerships for the goals & 3 & 0.82 \\
11. Sustainable cities and communities & 2 & 0.54 \\
15. Life on land & 2 & 0.54 \\
14. Life below water & 1 & 0.27 \\
\hline
\end{tabular}

Moreover, on the basis of conventional content analysis procedures in relation to the answers to question "Why is this Goal the most important for me?", 12 categories (plus the category "no answer") emerged (see Table 6). The relative frequency for each category is also shown in Table 8.

Table 8. Categories derived from analysis of answers to "Why is this the most important goal for me?".

\begin{tabular}{lcc}
\hline \multicolumn{1}{c}{ Category Title } & Frequency of Answer & \% of Responses \\
\hline Prerequisite for reaching other goals & 91 & 24.73 \\
No answer & 48 & 13.04 \\
Social justice & 43 & 11.68 \\
Safeguarding the planet and resources & 41 & 11.14 \\
Promotion of well-being & 28 & 7.61 \\
Human dignity & 27 & 7.34 \\
Development and growth of society & 23 & 6.25 \\
Safeguarding for future generations & 22 & 5.98 \\
Prerequisite for economic development and & 20 & 5.43 \\
growth & 11 & 2.99 \\
Practical personal contribution & 8 & 2.17 \\
Individual and social responsibility & 4 & 1.09 \\
Valorization of people & 2 & 0.54 \\
Freedom & & \\
\hline
\end{tabular}

The largest category considered received $24.73 \%$ of the answers (91 answers) and was named the "Prerequisite for reaching other goals". This goal emerged as the most important, based on the assumption that it permits the realization of the other goals. Some participants gave answers such as: "This goal is the most important for me because it allows progress toward the other goals"; "The goal is the most important because it represents the necessary foundation to be able to aspire to other goals".

The second largest category was "No answer", with 48 responses (13.04\%). Respondents provided no further elaboration of this answer.

The third largest category, "Social justice", comprised 43 responses (11.68\%). Examples of answers were: "It reduces inequalities, helping to foster social justice"; "It aims to defeat injustice in the world, promoting a sense of social justice".

The fourth largest category was called "Safeguarding the planet and resources" and received 41 answers (11.14\%). Some examples of participant responses follow: "This goal is the most important 
for me, because the exploitation of resources will lead the planet to destruction"; "I think that this goal is the most important, because it concerns the whole of humanity and all forms of life on the planet and therefore the survival of the planet itself".

The fifth largest category was "Promotion of well-being", comprising 28 answers (7.61\%). Some answers were: "This goal is the most important for me, because it is the basis of well-being; everything else is a direct correlation"; "This goal is the most important for me because it is essential to reach a state of well-being".

The sixth largest category, "Human dignity", drew 27 answers (7.34\%). Some participant answers were: "In my opinion, a lack of sustenance for the individual is not dignified"; "Without the realization of this goal, there is no dignity for the human being".

The next category, "Development and growth of society" included 23 answers (6.25\%). One participant explained: "This goal is the most important for me, because it is at the basis of the growth, quality, and improvement of a modern civil society from every point of view (growth, training, work, well-being...". Another participant stated, "In my opinion this goal is the most important because it leads to the growth and development of society".

The eighth largest category, "Safeguarding for future generations" had 22 answers (5.98\%) emphasizing the important of heritage to future generations. Examples of elaborations were: "This goal is the most important for me, as it seeks to guarantee the next generations a more just and equitable world"; "This goal is the most important for the growth of future generations".

The ninth largest category was titled "Prerequisite for economic development and growth" and included 20 answers $(5.43 \%)$ related to the fact that reaching a specific goal can permit economic development and growth to be realized. Some responses were: "This goal is the most important for economic development and growth"; "In my opinion, this goal is the most important, because it is at the heart of world development".

The tenth largest category, "Practical personal contribution" which comprised 11 answers (2.99\%), relates to the potential for the individual to act practically to attain a specific goal. Some responses were: "This goal is the most important for me, because we can act in the first person"; "This goal is the most important, because it is the only one where I feel I can really make a difference using my knowledge".

The eleventh category, "Individuals and social responsibility" included eight answers (2.17\%). Some respondents explained: "This goal is the most important for me, because it determines greater social responsibility, reflected in an environment that welcomes and respects people"; "This goal starts from every single individual carrying out a 'human revolution,' and, in doing so, every single individual has the responsibility for his/her actions".

The twelfth category, "Valorization of people" included four answers (1.09\%) and referred to the fact that the realization of a specific goal permits the valorization of each human being. Some elaborations were: "This goal is the most important for me, because only by maximizing each type of job role as a fundamental 'link' in a worked 'chain' can each individual take responsibility for his own role and work. In this way, each individual participates with his/her own commitment and productivity, creating added value and economic growth"; "To deserve to be recognized and valued as people, for what we can give, and not for our chromosomes".

The final category, "Freedom" which included two answers $(0.54 \%)$, signified the fact that the realization of a specific goal can permit an individual to attain freedom. Some answers were: "This goal gives one freedom to understand and act"; "This goal is the most important for me, because 'freedom' represents the starting point".

For the question "Which of the 17 Sustainable Development Goals is the least important for me?", the frequency of answers with respect to each of the 17 SDGs is reported in Table 9. Some participants answered in a general way, with, "No goal is the least important for me". 
Table 9. Answers to "Which of the 17 Sustainable Development Goals is the least important for me?".

\begin{tabular}{ccc}
\hline Sustainable Development Goal & Frequency of Answer & \% of Responses \\
\hline 14. Life below water & 90 & 24.46 \\
17. Partnerships for the goals & 88 & 23.91 \\
0. None (all important) & 87 & 23.64 \\
5. Gender equality & 21 & 5.71 \\
9. Industry, innovation and infrastructure & 20 & 5.43 \\
1. No poverty & 19 & 5.16 \\
10. Reduced inequalities & 10 & 2.72 \\
11. Sustainable cities and communities & 9 & 2.45 \\
13. Climate action & 7 & 1.90 \\
8. Decent work and economic growth & 5 & 0.36 \\
7. Affordable and clean energy & 3 & 0.82 \\
4. Quality education & 2 & 0.54 \\
6. Clean water and sanitation & 2 & 0.54 \\
12. Responsible consumption and production & 2 & 0.54 \\
2. Zero hunger & 1 & 0.27 \\
15. Life on land & 1 & 0.27 \\
16. Peace, justice, and strong institutions & 1 & 0.27 \\
\hline
\end{tabular}

Moreover, on the basis of the conventional content analysis procedures in relation to the answers to question "Why is this Goal the least important for me?", eight categories (plus the category "no answer") emerged (see Table 10). In the next table, the relative frequency for each category is given.

Table 10. Categories derived from analysis of answers to "Why is this the least important goal for me?".

\begin{tabular}{ccc}
\hline Category Title & Frequency of Answer & \% of Responses \\
\hline Low priority and urgency & 138 & 37.50 \\
Difficulty of reaching the goal & 80 & 21.74 \\
No answer & 72 & 19.57 \\
All important (all connected) & 27 & 7.34 \\
as an individual & 20 & 5.43 \\
Lack of interest & 19 & 5.16 \\
Impossibility of being able to take practical action & 8 & 2.17 \\
Consequence of the development of other goals & 2 & 0.54 \\
Already reached goal & 2 & 0.54 \\
\hline Lack of emotional involvement & & \\
\hline
\end{tabular}

The largest category in the analysis contained $37.50 \%$ of the answers (138 answers) and was named "Low priority and urgency". Participant explanations included: "This goal is the least important for me, because I believe it has a less acute impact on human life"; "In my opinion, this goal is the least important, because all the other goals have a greater impact on sustainable development".

The second largest category that emerged was "Difficulty of reaching the goal" with 80 responses $(21.74 \%)$. Some statements were: “This goal is the least important, because I don't think it's possible to realize it"; "This goal is the least important for me, because I don't think it is achievable".

The third largest category was "No answer" which received 72 responses (19.57\%). Participants who chose this response did not explain why any goal was the least important for them.

The fourth category, titled "All important (all connected)", comprised 27 answers $(7.34 \%)$, reflecting the fact that these participants thought all the goals were important. Some answered: "I don't think there are any less important goals. I couldn't name the least important one; they are all connected to one another and any one without the others would leave a 'void' for sustainable development"; "I can't define one of the 17 goals as less important; they are all part of a virtuous circle that I hope will start soon"; "They are all important because they are connected to one another". 
The fifth category, "Impossibility of personally taking practical action" attracted 20 answers (5.43\%). Some explained as follows: “This goal is the least important for me, because I feel I can't act, it doesn't totally depend on me"; "I'm not technically able to contribute"; "It depends on political will and it is not possible to act individually".

The sixth category, "Lack of interest" included 19 answers (5.16\%). Participants responded: "I'm not interested in this aspect of sustainability"; "I'm not informed about this at all and I'm not interested in it".

The seventh category, "Consequence of the development of other goals" included eight answers $(2.17 \%)$, signifying that a specific goal is not important because it will be achieved if the other goals are reached. Some answers are the following: "The development of this goal is the consequence of the development of other goals"; "This goal is a consequence of previous goals".

The eighth category, named "Already reached goal" contained two answers (0.54\%). Participants responded: "This is an aspect that already exists in reality"; "I believe we can already all consider ourselves equal".

The ninth category, "Lack of emotional involvement", also contained two answers (0.54\%). Some responses were: "This goal doesn't affect me emotionally like other goals"; "This goal is the least important for me, because it doesn't involve me emotionally".

\section{Discussion}

This study aimed to verify if the SDGPI realized by Di Fabio and Rosen has good reliability and validity referring to the Italian context, providing a thorough examination of the interest, motivation, and self-efficacy of Italian participants in relation to the 17 SDGs.

The evidence found that the SDGPI showed adequate psychometric properties. The dimensionality assessment through EFA revealed three unidimensional factors (interest, motivation, and self-efficacy). These three factors showed good reliability, in terms of Cronbach's alpha, which also supported their internal consistency.

With regard to aspects of concurrent validity, positive and significant relationships emerged between the three unidimensional factors, interest, motivation, and self-efficacy, with connectedness to nature, empathy, compassion, and purpose. This pattern of correlations underlined that these psychological aspects with respect to the SDGs are associated with a perception of being connected to nature as part of the broader natural world $[55,66]$, a perception of being more empathetic [56] and compassionate toward others [57], and a perception of having a life purpose [58]. Interest, motivation and self-efficacy relative to the SDGs seem to be positively associated with care and consideration for the natural world and for other people as well as aspects relative to purpose in terms of meaningfulness and self-orientation. This means that individuals more sensitive to nature and other human beings seem to have also more interest in the promotion of sustainable development goals and also to be more motivated to pursuit them and to have more confidence in themselves regarding the possibility to reach them.

The qualitative analysis of the responses to open-ended questions enhanced the understanding of participants' self-perceptions of the SDGs, widening the view on the constructs in addition to quantitative results.

With respect to the open-ended question "Which of the 17 Sustainable Development Goals is the most important for me?" (see Table 5), the participants particularly stressed Goal 4 "Quality of education" (14.13\%), Goal 3 "Good health and well-being" (13.04\%), Goal 1 "No poverty" (12.50\%), and Goal 13 "Climate action" (11.96\%). The other goals were rated with percentages lower than 10\%. The least important goals were identified as Goal 14 "Life below water" (0.27\%), Goal 15 "Life on land" $(0.54 \%)$, Goal 11, "Sustainable cities and communities" (0.54\%), and Goal 17 "Partnerships for the goals" $(0.82 \%)$.

Regarding the question "Why is this Goal the most important goal for me?", categories of responses emerged in the following order (see Table 6): importance for reaching other goals, no 
answer, social justice, safeguarding the planet and resources, promotion of well-being, human dignity, development and growth of society, safeguarding for future generations, economic development and growth, practical personal contribution, individual and social responsibility, valorization of people, and freedom. These qualitative results permitted the delineation of categories of participants' reasons for identifying particular SDGs as the most important. Regarding this question, it is noted that the higher frequency of people have given "no answer" when they were asked about the reason why the goal they indicated was the most important for him/her. This probably occurred because they recognized the importance of the goal itself for sustainable development and they do not feel the need to add any additional reasons or they found it difficult to explain reasons for the importance.

From the results reported in Tables 5 and 6, we might surmise that the goals that were deemed most important were those that enabled the attainment of other broad goals, such as realizing social justice and safeguarding the planet and resources. By contrast, the goals ranked least important (for example, Goal 14 "Life below water" and Goal 15 "Life on land") were perhaps so considered because they were not relevant, first, for the realization of other goals and, second, in relation to social justice and the safeguarding of the planet. On the basis of these results, it could be a promising initiative to create interventions to increase the awareness of the importance of the goals "Life below water" and "Life on land", by stimulating people's interest, motivation, and self-efficacy. Regarding Goals 14 "Life below water" and 17 "Partnerships for the goals", $24.46 \%$ and $23.91 \%$ of the participants, respectively, identified them as the least important. On the other hand, $23.64 \%$ of the participants declared that all goals are important. Goals that achieved low rankings of importance were: Goal 16 "Peace, justice and strong institutions" (0.0\%), Goal 15 "Life on land" (0.27\%), Goal 3 "Good health and well-being" $(0.27 \%)$, and Goal 2 "Zero hunger" $(0.27 \%)$.

Regarding the question, "Why is this Goal the least important for me?" categories of responses emerged in the following order (see Table 8): low priority and urgency, difficulty of reaching the goal, no answer, all important, impossibility of personally taking practical action, lack of interest, consequence of the development of other goals, already reached the goal, and lack of emotional involvement. These results gave an indication of the motivation of the participants toward the SDGs. The results reported in Tables 7 and 8 suggest that Goal 14 "Life below water" was ranked the least important, possibly because, first, it was perceived to have low priority and urgency and, second, because it was perceived as difficult to attain. These results confirm those reported in Table 5 . In relation to the participants in this study, these results permit delineation of the value of intervention to enhance the level of awareness regarding the importance of life below water augmenting their interest, motivation, and self-efficacy. Overall, taking into consideration the results about the most and least important sustainable development goals and the reasons for the participants in the present study, it is possible to provide interventions for enhancing interest, motivation, and self-efficacy in particular regarding such goals as "Life below water", "Life on land" and "Partnerships for the goals". These interventions could increase the understanding of the meaning of these goals and could stimulate the awareness of participants regarding their importance for reaching the other goals and for realizing sustainable development.

Furthermore, the qualitative results permitted additional information to be obtained in relation to interest, motivation and self-efficacy, compared with the quantitative results. It is noted that the results of the exploratory factor analysis showed the best saturation for Goal 11 "Sustainable cities and communities" both for interest and motivation, and the second-best saturation for self-efficacy. Instead, when participants were asked to evaluate the importance of this goal, it emerged in the third to last position. The qualitative analysis allowed an enhanced understanding of participants' self-perceptions of the SDGs, highlighting aspects of the importance of the goals that could be important for the concrete realization of a specific goal.

Although the present study has yielded some promising results, it has some limitations. The participants do not represent the national context fully and the sample size was limited, so the results cannot be viewed as generalizable. Therefore, in future research, a more broadly representative 
sample of the Italian population, including participants from different geographic areas of the country, could be used. The results could also be compared with those obtained in other countries. It also could be interesting to administer the Sustainable and Development Goals Psychological Inventory during the COVID-19 pandemic to obtain a thorough comprehension of the self-perceptions of the sustainable development goals during this specific period. Future studies should also verify the factor structure of the Sustainable Development Goals Psychological Inventory through a confirmatory factor analysis. It could be also interesting to consider other aspects that may activate interest in the sustainable development goals and also could be associated with motivation and self-efficacy, such as values and meaning. It would be informative to study the relationship between the motivation to work concretely toward a specific sustainable development goal and the reasons given to explain why a specific goal is the most/the least important.

Nevertheless, the Sustainable Development Goals Psychological Inventory, offered for the first time in this study, represents an instrument capable of accurately detecting the self-perceptions of participants in relation to the 17 SDGs. It allows for the assessment of the psychological aspects of interest, motivation, and self-efficacy, which are known to be associated with the performance and actions of individuals, and, in this context, environmentally protective and responsible behaviors. Such an assessment of these three psychological aspects could assist in designing tailored interventions in relation to specific targets, contexts, and needs, and thereby stimulate practical action.

Furthermore, the qualitative approach could permit a more in-depth understanding of self-perceptions about the SDGs from the perspective of the participants in this study, allowing a wider prospect for considering this theme.

This instrument may also open new study and intervention opportunities for understanding the psychology of sustainable development and sustainability from perspectives of primary prevention and strength-based prevention, thereby contributing to the concrete realization of the 17 SDGs.

\section{Conclusions}

The results and findings suggest that the Sustainable Development Goals Psychological Inventory constitutes a reliable and valid instrument for conducting research on sustainability and sustainable development, taking into account critical psychological aspects involved in the self-perception of the SDGs, namely interest, motivation, and self-efficacy. The instrument thus can be of assistance by contributing to the concrete and progressive realization of the goals. With regard to interventions, the SDGPI could be used in varied and different national and international contexts, with numerous and different targets, at different age levels, with a life-span perspective, to evaluate their self-perceptions of sustainable development goals and their levels of interest, motivation and self-efficacy regarding each goal. The use of the SDGPI could also have practical policy implications, since it could be a useful instrument for policy makers who want to promote sustainable development in their countries and to implement intervention strategies that include psychological aspects, doing so seems important for a practical path to action.

The inventory could be useful for comparing and reflecting on results at various levels, from more limited geographic contexts to international ones, to enhance awareness and offer tailor-made communication and interventions suitable for all school levels, ages, cultures, geographic contexts, and so on. These findings could also contribute to public policy-making and organizational initiatives to promote the SDGs, by considering the psychological variables that contribute to their realization.

Author Contributions: Conceptualization, A.D.F. and M.A.R.; Data curation, A.D.F. and M.A.R.; Investigation, A.D.F.; Methodology, A.D.F. and M.A.R.; Writing—original draft, A.D.F.; Writing—review \& editing, M.A.R. All authors have read and agreed to the published version of the manuscript.

Funding: This research received no external funding.

Conflicts of Interest: The authors declare no conflict of interest. 


\section{Appendix A. The Sustainable Development Goals Psychological Inventory}

Instructions: The sustainable development goals (SDGs) are a set of 17 global goals agreed to by the United Nations General Assembly. Please indicate your rankings first for all the items in column A, then for those in column B, and finally for those in column $C$. There are no right or wrong answers. Please use the following rankings: $1=$ not at all; $2=$ a little; $3=$ somewhat; $4=$ quite a lot; $5=$ very much.

\begin{tabular}{|c|c|c|c|c|c|c|c|c|c|c|c|c|c|c|c|}
\hline \multicolumn{16}{|c|}{ The Sustainable Development Goals Psychological Inventory } \\
\hline \multirow{2}{*}{$\begin{array}{c}\text { Regarding each of the following } 17 \\
\text { Sustainable Development Goals (SDGs) to } \\
\text { what extent }\end{array}$} & \multicolumn{5}{|c|}{ A } & \multicolumn{5}{|c|}{ B } & \multicolumn{5}{|c|}{$\mathrm{C}$} \\
\hline & \multicolumn{5}{|c|}{ I'm interested in } & \multicolumn{5}{|c|}{$\begin{array}{l}\text { I'm motivated to } \\
\text { act concretely for }\end{array}$} & \multicolumn{5}{|c|}{$\begin{array}{l}\text { I feel able to } \\
\text { act concretely } \\
\text { for }\end{array}$} \\
\hline 1. No poverty & 1 & 2 & 3 & 4 & 5 & 1 & 2 & 3 & 4 & 5 & 1 & 2 & 3 & 4 & 5 \\
\hline 2. Zero hunger & 1 & 2 & 3 & 4 & 5 & 1 & 2 & 3 & 4 & 5 & 1 & 2 & 3 & 4 & 5 \\
\hline 3. Good health and well-being & 1 & 2 & 3 & 4 & 5 & 1 & 2 & 3 & 4 & 5 & 1 & 2 & 3 & 4 & 5 \\
\hline 4. Quality education & 1 & 2 & 3 & 4 & 5 & 1 & 2 & 3 & 4 & 5 & 1 & 2 & 3 & 4 & 5 \\
\hline 5. Gender equality & 1 & 2 & 3 & 4 & 5 & 1 & 2 & 3 & 4 & 5 & 1 & 2 & 3 & 4 & 5 \\
\hline 6. Clean water and sanitation & 1 & 2 & 3 & 4 & 5 & 1 & 2 & 3 & 4 & 5 & 1 & 2 & 3 & 4 & 5 \\
\hline 7. Affordable and clean energy & 1 & 2 & 3 & 4 & 5 & 1 & 2 & 3 & 4 & 5 & 1 & 2 & 3 & 4 & 5 \\
\hline 8. Decent work and economic growth & 1 & 2 & 3 & 4 & 5 & 1 & 2 & 3 & 4 & 5 & 1 & 2 & 3 & 4 & 5 \\
\hline 9. Industry, innovation, and infrastructure & 1 & 2 & 3 & 4 & 5 & 1 & 2 & 3 & 4 & 5 & 1 & 2 & 3 & 4 & 5 \\
\hline 10. Reducing inequalities & 1 & 2 & 3 & 4 & 5 & 1 & 2 & 3 & 4 & 5 & 1 & 2 & 3 & 4 & 5 \\
\hline 11. Sustainable cities and communities & 1 & 2 & 3 & 4 & 5 & 1 & 2 & 3 & 4 & 5 & 1 & 2 & 3 & 4 & 5 \\
\hline 12. Responsible consumption and production & 1 & 2 & 3 & 4 & 5 & 1 & 2 & 3 & 4 & 5 & 1 & 2 & 3 & 4 & 5 \\
\hline 13. Climate action & 1 & 2 & 3 & 4 & 5 & 1 & 2 & 3 & 4 & 5 & 1 & 2 & 3 & 4 & 5 \\
\hline 14. Life below water & 1 & 2 & 3 & 4 & 5 & 1 & 2 & 3 & 4 & 5 & 1 & 2 & 3 & 4 & 5 \\
\hline 15. Life on land & 1 & 2 & 3 & 4 & 5 & 1 & 2 & 3 & 4 & 5 & 1 & 2 & 3 & 4 & 5 \\
\hline 16. Peace, justice, and strong institutions & 1 & 2 & 3 & 4 & 5 & 1 & 2 & 3 & 4 & 5 & 1 & 2 & 3 & 4 & 5 \\
\hline 17. Partnerships for the goals & 1 & 2 & 3 & 4 & 5 & 1 & 2 & 3 & 4 & 5 & 1 & 2 & 3 & 4 & 5 \\
\hline
\end{tabular}

\section{References}

1. Dincer, I.; Rosen, M.A. Exergy, Environment and Sustainable Development, 2nd ed.; Elsevier: Amsterdam, The Netherlands, 2007.

2. Rosen, M.A. Energy Sustainability: A Pragmatic Approach and Illustrations. Sustainability 2009, 1, 55-80. [CrossRef]

3. Rosen, M.A. Sustainable Development: A Vital Quest. Eur. J. Sustain. Dev. Res. 2017, 1, 2-14. [CrossRef]

4. Rosen, M.A. Issues, concepts and applications for sustainability. Glocalism J. Cult. Politics Innov. 2018, 3, 1-21.

5. Di Fabio, A.; Rosen, M.A. Opening the Black Box of Psychological Processes in the Science of Sustainable Development: A New Frontier. Eur. J. Sustain. Dev. Res. 2018, 2, 47. [CrossRef]

6. United Nations about the Sustainable Development Goals 2018. 2018. Available online: https://www.un.org/ (accessed on 2 April 2020).

7. Di Fabio, A. Positive Healthy Organizations: Promoting Well-Being, Meaningfulness, and Sustainability in Organizations. Front. Psychol. 2017, 8, 1938. [CrossRef]

8. Di Fabio, A. The Psychology of Sustainability and Sustainable Development for Well-Being in Organizations. Front. Psychol. 2017, 8, 1534. [CrossRef]

9. Brundtland, G.H. Our Common Future-Call for Action. Environ. Conserv. 1987, 14, 291-294. [CrossRef]

10. Harris, J.M. Sustainability and sustainable development. Int. Soc. Ecol. Econ. 2003, 1, 1-11.

11. Di Fabio, A.; Kenny, M.E. The Contributions of Emotional Intelligence and Social Support for Adaptive Career Progress among Italian Youth. J. Career Dev. 2014, 42, 48-59. [CrossRef]

12. Di Fabio, A.; Kenny, M.E. From Decent Work to Decent Lives: Positive Self and Relational Management (PS\&RM) in the Twenty-First Century. Front. Psychol. 2016, 7, 361. [CrossRef] 
13. Di Fabio, A.; Kenny, M.E. Connectedness to nature, personality traits and empathy from a sustainability perspective. Curr. Psychol. 2018, 1-12. [CrossRef]

14. Kenny, M.E.; Hage, S.M. The Next Frontier: Prevention as an Instrument of Social Justice. J. Prim. Prev. 2008, 30, 1-10. [CrossRef]

15. Hage, S.M.; Romano, J.L.; Conyne, R.K.; Kenny, M.; Matthews, C.; Schwartz, J.P.; Waldo, M. Best Practice Guidelines on Prevention Practice, Research, Training, and Social Advocacy for Psychologists. Couns. Psychol. 2007, 35, 493-566. [CrossRef]

16. Di Fabio, A.; Saklofske, D.H. Comparing ability and self-report trait emotional intelligence, fluid intelligence, and personality traits in career decision. Pers. Individ. Differ. 2014, 64, 174-178. [CrossRef]

17. Di Fabio, A.; Saklofske, D.H. Promoting individual resources: The challenge of trait emotional intelligence. Pers. Individ. Differ. 2014, 65, 19-23. [CrossRef]

18. Di Fabio, A.; Saklofske, D.H. The Contributions of Personality Traits and Emotional Intelligence to Intrapreneurial Self-Capital: Key Resources for Sustainability and Sustainable Development. Sustainability 2019, 11, 1240. [CrossRef]

19. Di Fabio, A.; Peiró, J.M. Human Capital Sustainability Leadership to Promote Sustainable Development and Healthy Organizations: A New Scale. Sustainability 2018, 10, 2413. [CrossRef]

20. Chams, N.; García-Blandón, J. On the importance of sustainable human resource management for the adoption of sustainable development goals. Resour. Conserv. Recycl. 2019, 141, 109-122. [CrossRef]

21. Dahlmann, F.; Stubbs, W.; Griggs, D.; Morrell, K. Corporate actors, the UN Sustainable Development Goals and Earth System Governance: A research agenda. Anthr. Rev. 2019, 6, 167-176. [CrossRef]

22. Dickens, C.; Smakhtin, V.; McCartney, M.; O’Brien, G.; Dahir, L. Defining and Quantifying National-Level Targets, Indicators and Benchmarks for Management of Natural Resources to Achieve the Sustainable Development Goals. Sustainability 2019, 11, 462. [CrossRef]

23. Horne, J.; Recker, M.; Michelfelder, I.; Jay, J.; Kratzer, J. Exploring entrepreneurship related to the sustainable development goals-mapping new venture activities with semi-automated content analysis. J. Clean. Prod. 2020, 242, 118052. [CrossRef]

24. Salvia, A.L.; Filho, W.L.; Brandli, L.L.; Griebeler, J.S. Assessing research trends related to Sustainable Development Goals: Local and global issues. J. Clean. Prod. 2019, 208, 841-849. [CrossRef]

25. Yap, M.L.-M.; Watene, K. The Sustainable Development Goals (SDGs) and Indigenous Peoples: Another Missed Opportunity? J. Hum. Dev. Capab. 2019, 20, 451-467. [CrossRef]

26. Zimon, D.; Tyan, J.; Sroufe, R. Drivers of sustainable supply chain management: Practices to alignment with un sustainable development goals. Int. J. Qual. Res. 2020, 14, 219-236. [CrossRef]

27. Alvarez-Risco, A.; Rosen, M.A.; Marinova, D.; Del-Aguila-Arcentales, S. Building Sustainable Cities: Social, Economic and Environmental Factors; Springer: Cham, Switzerland, 2020.

28. Rosen, M.A. Do Universities Contribute to Sustainable Development? Eur. J. Sustain. Dev. Res. 2019, 4, em0112. [CrossRef]

29. Bandura, A. Social Foundations of Thought and Action: A Social Cognitive Theory; Prentice-Hall: Englewood Cliffs, NJ, USA, 1986.

30. Lent, R.W.; Brown, S.D.; Hackett, G. Toward a Unifying Social Cognitive Theory of Career and Academic Interest, Choice, and Performance. J. Vocat. Behav. 1994, 45, 79-122. [CrossRef]

31. Lent, R.W.; Brown, S.D.; Hackett, G. Contextual supports and barriers to career choice: A social cognitive analysis. J. Couns. Psychol. 2000, 47, 36-49. [CrossRef]

32. Deci, E.L.; Ryan, R.M. Intrinsic Motivation and Self-Determination in Human Behavior; Plenum: New York, NY, USA, 1985.

33. Ryan, R.M.; Deci, E.L. Self-determination theory and the facilitation of intrinsic motivation, social development, and well-being. Am. Psychol. 2000, 55, 68-78. [CrossRef]

34. Ryan, R.M.; Deci, E.L. Self-Determination Theory: Basic Psychological Needs in Motivation, Development, and Wellness; Guilford Publications: New York, NY, USA, 2017.

35. Reeve, H.K. The Evolution of Conspecific Acceptance Thresholds. Am. Nat. 1989, 133, 407-435. [CrossRef]

36. Hidi, S.; Berndorff, D.; Ainley, M. Children's argument writing, interest and self-efficacy: An intervention study. Learn. Instr. 2002, 12, 429-446. [CrossRef] 
37. Chen, J.A.; Tutwiler, M.S.; Metcalf, S.J.; Kamarainen, A.; Grotzer, T.; DeDe, C. A multi-user virtual environment to support students' self-efficacy and interest in science: A latent growth model analysis. Learn. Instr. 2016, 41, 11-22. [CrossRef]

38. Grigg, S.; Perera, H.N.; McIlveen, P.; Svetleff, Z. Relations among math self efficacy, interest, intentions, and achievement: A social cognitive perspective. Contemp. Educ. Psychol. 2018, 53, 73-86. [CrossRef]

39. Lent, R.W.; Larkin, K.C.; Brown, S.D. Relation of self-efficacy to inventoried vocational interests. J. Vocat. Behav. 1989, 34, 279-288. [CrossRef]

40. Harackiewicz, J.M.; Canning, E.A.; Tibbetts, Y.; Priniski, S.J.; Hyde, J.S. Closing achievement gaps with a utility-value intervention: Disentangling race and social class. J. Pers. Soc. Psychol. 2015, 111, 745-765. [CrossRef]

41. Pinxten, M.; Marsh, H.W.; De Fraine, B.; Noortgate, W.V.D.; Van Damme, J. Enjoying mathematics or feeling competent in mathematics? Reciprocal effects on mathematics achievement and perceived math effort expenditure. Br. J. Educ. Psychol. 2013, 84, 152-174. [CrossRef]

42. Wang, M.-T. Educational and career interests in math: A longitudinal examination of the links between classroom environment, motivational beliefs, and interests. Dev. Psychol. 2012, 48, 1643-1657. [CrossRef]

43. Wang, X. Why Students Choose STEM Majors. Am. Educ. Res. J. 2013, 50, 1081-1121. [CrossRef]

44. Shin, J.; Grant, A.M. Bored by Interest: How Intrinsic Motivation in One Task Can Reduce Performance on Other Tasks. Acad. Manag. J. 2019, 62, 415-436. [CrossRef]

45. Elliot, A.J.; Fryer, J.W. The goal construct in psychology. In Handbook of Motivation Science; Shah, J.Y., Gardner, W.L., Eds.; The Guilford Press: New York, NY, USA, 2008; pp. 235-250.

46. Mitchell, J.V. Interrelationships and predictive efficacy for indices of intrinsic, extrinsic, and self-assessed motivation for learning. J. Res. Dev. Educ. 1992, 25, 149-155.

47. Phares, E.J.; Chaplin, W.F. Introduction to Personality, 4th ed.; Longman: New York, NY, USA, 1997.

48. Locke, E.A.; Latham, G.P. A Theory of Goal Setting and Task Performance; Prentice-Hall: Upper Saddle River, NJ, USA, 1990.

49. Kruglanski, A.W. Motivated social cognition: Principles of the interface. In Social Psychology: Handbook of Basic Principles; Higgins, E.T., Kruglanski, A.W., Eds.; The Guilford Press: New York, NY, USA, 1996; pp. 493-520.

50. Caprara, G.V.; Cervone, D. Personality: Determinants, Dynamics, and Potentials; Cambridge University Press (CUP): Cambridge, UK, 2000.

51. Ferguson, E.D.; Wee, B.E.F. Motivation: A Biosocial and Cognitive Integration of Motivation and Emotion; Oxford University Press: London, UK, 2000.

52. Deckers, L. Motivation: Biological, Psychological, and Environmental, 5th ed.; Routledge: London, UK, 2018.

53. Dweck, C.S. Motivational processes affecting learning. Am. Psychol. 1986, 41, 1040-1048. [CrossRef]

54. Di Fabio, A.; Saklofske, D.H. Positive Relational Management for Sustainable Development: Beyond Personality Traits-The Contribution of Emotional Intelligence. Sustainability 2019, 11, 330. [CrossRef]

55. Mayer, F.; Frantz, C.M. The connectedness to nature scale: A measure of individuals' feeling in community with nature. J. Environ. Psychol. 2004, 24, 503-515. [CrossRef]

56. Davis, M.H. A multidimensional approach to individual differences in empathy. JSAS Cat. Select. Doc. Psychol. 1980, 10, 85.

57. Gu, J.; Cavanagh, K.; Baer, R.; Strauss, C. An empirical examination of the factor structure of compassion. PLoS ONE 2017, 12, e0172471. [CrossRef] [PubMed]

58. Bronk, K.C.; Riches, B.R.; Mangan, S.A. Claremont Purpose Scale: A Measure that Assesses the Three Dimensions of Purpose among Adolescents. Res. Hum. Dev. 2018, 15, 101-117. [CrossRef]

59. Kılkış, Ş.; Krajačić, G.; Duić, N.; Montorsi, L.; Wang, Q.; Rosen, M.A.; Al-Nimr, M.A. Research frontiers in sustainable development of energy, water and environment systems in a time of climate crisis. Energy Convers. Manag. 2019, 199, 111938. [CrossRef]

60. Di Fabio, A. Green positive guidance and life counseling: New perspectives and first contribution to the Italian validation of the Connectedness to Nature Scale. Couns. Giorn. Ital. Ric. Appl. 2016, 9. Available online: https://rivistedigitali.erickson.it/counseling/archivio/vol-9-n-1/ (accessed on 2 April 2020).

61. Albiero, P.; Ingoglia, S.; Lo Coco, A. Contributo all'adattamento italiano dell'Interpersonal Reactivity Index [Contribution to the Italian validation of the Interpersonal Reactivity Index]. TPM 2006, 13, 107-125. 
62. Di Fabio, A. Compassion Scale: Proprietà psicometriche della versione italiana [Compassion Scale: Psychometric properties of the Italian version]. Couns. Giorn. Ital. Ric. Appl. 2019, 12, 51-55. [CrossRef]

63. Di Fabio, A.; Kenny, M.E. Claremont Purpose Scale: Psychometric properties of the Italian validation for workers. Couns. Giorn. Ital. Ric. Appl. 2019, 12. [CrossRef]

64. Hsieh, H.-F.; Shannon, S.E. Three Approaches to Qualitative Content Analysis. Qual. Health Res. 2005, 15, 1277-1288. [CrossRef] [PubMed]

65. Braun, V.; Clarke, V. Thematic analysis. In APA Handbook of Research Methods in Psychology; Cooper, H., Ed.; American Psychological Association: Washington, DC, USA, 2012.

66. Di Fabio, A.; Rosen, M.A. Accounting for Individual Differences in Connectedness to Nature: Personality and Gender Differences. Sustainability 2019, 11, 1693. [CrossRef]

(C) 2020 by the authors. Licensee MDPI, Basel, Switzerland. This article is an open access article distributed under the terms and conditions of the Creative Commons Attribution (CC BY) license (http://creativecommons.org/licenses/by/4.0/). 